\title{
The effects of higher education and financial literacy to pro-environmental behavior in women community
}

\author{
Donna Asteria ${ }^{1}$, Habibulah Adi Negoro ${ }^{2}$, Dyah Utari $^{3}$ \\ ${ }^{1}$ Department of Communication, Faculty of Social and Political Science, Universitas \\ Indonesia, Depok, West Java 16424, Indonesia \\ ${ }^{2}$ Faculty of Economic and Business, Universitas Indonesia, Depok, West Java 16424, \\ Indonesia \\ ${ }^{3}$ Faculty of Health Science, Universitas Pembangunan Nasional Veteran, Limo Depok, West \\ Java 16515 Indonesia
}

\begin{abstract}
It is assumed that efforts to overcome environmental problems in urban areas can be overcome through education. The education provided to women will increase women's contributions as strategic actors in environmental management. This study aimed to determine the effect of formal education and financial education on women on pro-environmental behavior. The research was conducted with a quantitative approach, with a survey by questionnaire to measure pro-environmental education and behavior based on women's participation in waste management training. The primary data collection with purposive sampling to women population in Jagakarsa District, South Jakarta, Indonesia, where fair women who were recorded in essential information collection. The study has been driven on a person-level (not family level), with a total of 400 respondents. The findings in this study are that there is a significant relationship between formal education in higher education and women's involvement in environmental management. Meanwhile, the relationship between financial literacy and environmental concerns shows insignificant results. The implication of this research is to provide alternative strategies to increase the involvement of women in urban areas in environmental management, especially waste management, through policies of equal access to higher education and equal opportunities in economic activities to improve their welfare.
\end{abstract}

\section{Introduction}

The impact of global warming on environmental degradation will threaten the resilience of cities. The involvement of all communities is essential to overcome environmental problems that occur and achieve sustainability. On the Sustainable Development Goals (SDGs) with the fourth goal emphasizing higher education. Higher education aims to shape human resources by developing knowledge to increase added value in sustainable development implementation. Goal number 4 regarding higher education is an important part of other SDGs goals in the poverty 
aspect (SDGs number 1); health and welfare (SDGs number 3); gender equality (SDGs number 5); decent work and economic growth (in SDGs number 8); responsible consumption and production (SDGs number 12); climate change (SDGs number 13); and peace, justice and strong institutions (SDGs number 16).

The formation of environmental awareness and concern to overcome environmental problems can be done through education. Education is a strategy to teach individuals how to think and build awareness as a base of behavioral changes and prepare human capital. Education is a right that must be given to all people. Even though women are included in the marginalized group in urban development, women have a role in environmental management. However, the impact of disasters due to climate change and unsustainable development has led to gender inequality because women and girls' position is often disproportionate due to economic, social and environmental pressures [1]. In this regard, it is essential to involve and provide women access, as a key element to achieve sustainable development is to involve women. Because environmental literacy among women based on their experience in managing waste must be done from the source, namely household waste management [2]. The involvement of women in environmental management is related to achieving gender equality following SDGs number 5 .

Several studies regarding pro-environmental attitudes and behavior show that respondents with a higher education level are consistently more likely to carry out all environmental awareness activities and increase the capacity for proenvironmental activities than respondents who have a lower education level and complete their education earlier. The research proves that higher education levels correlate with a higher probability of pro-environmental behavior [3]. More highly educated Chinese citizens in China have a higher level of environmental awareness [4]. Higher education is a type of formal education that focuses on forming cultural knowledge and general thinking skills. Formal education focuses on the formation of cultural knowledge and thinking skills broadly. Meanwhile, financial education is closely related to individuals' ability as consumers who can manage their finances and make savings in making decisions for purchasing goods (consumption). Knowledge and ability to manage finances are called financial literacy related to the life cycle and human capital [5].

Concerning urban sustainability, the problem of waste that has not been managed in an integrated manner starting from the first source (household level) is an urgent environmental problem to be overcome so as not to cause flood disasters and environmental pollution. This emphasizes pro-environmental behavior to be focused on efforts to increase knowledge to handle the waste. This research was conducted only on women to test the effects of formal education and financial education. It is essential to know the conditions and educational strategies that can increase women's environmental management involvement. The education provided to women will increase women's contributions as strategic actors in environmental management. This study aimed to determine the effect of formal education and financial education on women on pro-environmental behavior.

In Meyer (2015), there is a relationship between higher education levels and concern for the environment; education is also positively correlated with proenvironmental behavior. The pro-environmental behavior consists of habits that do not exacerbate environmental damage, save energy, and pay attention to consumption methods, including by traveling in an environmentally friendly manner, reducing consumption of disposable items (including reducing plastic use), 
waste management with the $3 \mathrm{R}$ principle (reduce, reuse, recycle), reduce water and energy consumption, purchase environmentally friendly products, and use local products [6]. Previous studies regarding the relationship between education and proenvironmental behavior did not specifically explain certain gender aspects or individual internal and external conditions that reinforce the correlation. An example of a variety of studies its found that college-educated individuals tend to be more willing to sacrifice financially to improve environmental quality [7], higher education levels are associated with energy-saving behavior [8], and the length of time taking formal education is an important aspect to explain pro-environmental attitudes, as well as informal education related to political interests related to environmental activities [9].

With regard to sustainable development goals, education is essential to empower women in supporting gender equality. Access to education for women will support the sustainable development of women's leadership roles in environmental management [10]. To achieve the success of the 2030 Agenda for Sustainable Development, gender equality is a fundamental human right, and efforts to conserve the environment locally and globally require the participation of women.

This study's novelty is to examine the effect of financial education as part of awareness as a consumer as a factor that shapes environmental awareness behavior. This is because consumer awareness in consuming products is essential in environmental awareness related to waste management. Other research on the effect of education on pro-environmental behavior as a causative factor focuses more on the types of formal and informal education with material on environmental awareness. So the state of the art of this research is trying to fill the gaps from previous studies.

As in the conceptual framework in Figure 1, in this study, the education aspect is divided into higher education and financial education, where financial education is measured by financial literacy as a conceptual derivative. To measure proenvironmental behavior, it is assumed in the form of women's participation in participating in waste handling training as an effort to increase women's knowledge of waste management. The context was chosen to participate in waste management training because waste is one of the sources of environmental pollution that causes environmental degradation in cities, even natural disasters, floods and disease outbreaks.

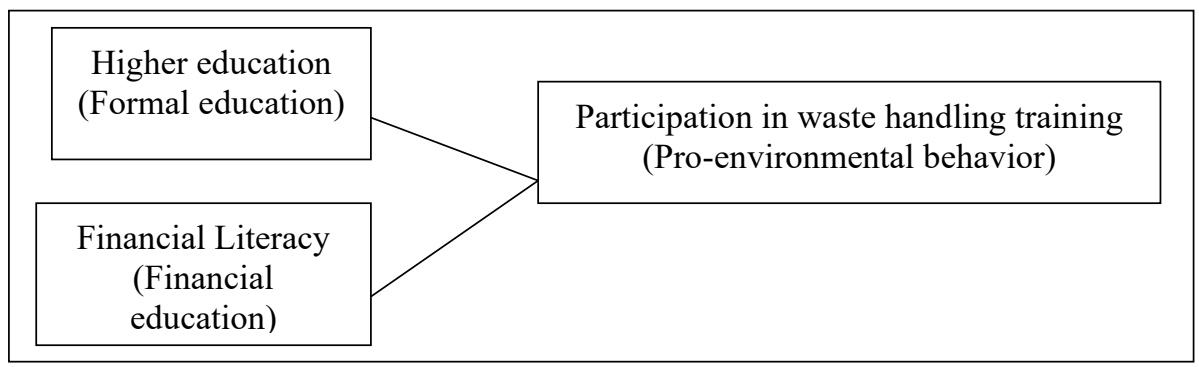

(Source: Private document, 2020)

Fig 1. Conceptual framework 


\section{Method}

The research was conducted with a quantitative approach, with a survey by a questionnaire to measure pro-environmental education and behavior based on women's participation in waste management training. The research location was chosen in Jakarta as the capital city of Indonesia is still experiencing floods due to unresolved waste problems, with a specific of survey location at Jagakarsa District, South Jakarta because since 2018, the World Clean Up Day Junior Chamber International (JCI) Jakarta activities and the South Jakarta Clean Up program (it's called "Bersih-Bersih Jakarta Selatan"/BBJS program) have been carried out as a form of an education program for the community carried out. By the South Jakarta, Regional Government reduces the volume of waste in Jakarta and as socialization to residents to be more concerned about the environment. Also, based on data from the South Jakarta Central Statistics Agency, in 2019 for the South Jakarta area, Jagakarsa District has the largest number of the female population than other subdistricts in the South Jakarta area [11].

The primary data collection with purposive sampling to women population in Jagakarsa District, South Jakarta, Indonesia, where fair women who were recorded in essential information collection. The study has been driven on person level (not family level), with 400 respondents. The study has been done inside 3 weeks, started in late December 2019 until mid-January 2020. Ladies have been taken portion in this outline begin from distinctive educator establishment, moreover with their economic status and age. The study comprises over 60 questions, with 20 essential questions with a couple of branches off questions. Respondents were gotten some information about their educational background, length of living in their present house, the viewpoint of what issues looked in the city, economic status, and their possibility of specific experience in discrimination, equality, governance, safety, knowledge, access to work showcase, environmental and financial aspects. Both dependent and independent ladies took portion on the primary data collection, in any case, their marital status. In this study author analyzes how far financial literacy and education matter to the likelihood of enrollment in waste-handling training.

\subsection{Analysis technique with Logistic Regression Technique}

\subsubsection{Operationalizing concepts and measurements}

There are questions with inquiring guided self-assessed score of chance to gain particular involvement in different angles on the questionnaire. Each request (from 40 request) offers 1 to 5 score of chance, where 1 stands for exceptionally to 5 which stands for exceptionally tall. These 40 sub-inquiries must be totally replied by the respondents, to infer a few conceivable score of chances. After the study information had been handled and the data were cleaned, creator has isolated and gathered the answer of question number 20 (which has 40 sub-inquiries) into 10 conceivable score of chances. In this study, chance of getting higher education and chance of financially literate were the main score of chances used in this study, among other 10 conceivable score of chances in particular encounters. The chance 
of getting higher education and chance of financially literate will be the variables of interest analysed in this study.

In this study, women's pro-environmental behavior is measured on their willingness to participate on waste-handling training, regardless the holding organizer. The primary data collection asks whether the respondent participated in waste-handling training in the past 3 months, given their backgrounds or socioeconomic conditions. On the other words, this article measures how women will likely to participate on waste-handling training, given their current financial literacy, educations and other socio-economic factors.

To estimate the willingness to participate on environmental preservations, especially waste-handling training, logistic regression method has been used in this article, where the participation in waste-handling training in last 3 months became the dependent variable. The dependent variable stated as dummy, as the logistic regression technique has been used. The 1 on the dependent variable's dummy stands for attended training, while 0 stands for did not attend. In this study, the author regressed the dependent variable with several variable of interest, such are the score of a chance to get higher education and chance of financially literate. Furthermore, the dependent variable also regressed with other socioeconomic factors such as education level, respondents' main activities, economic status, and technological exposures.

This study has two variables of interest as independent variables: score of the chance to access higher education and score of chance to be financially literate. Another score of chance is also included: the chance of getting good environment of living, although it doesn't include as variable of interest. The primary data collection has gathered many possibilities to form score of chance in specific experiences. In this study, each possibility of specific experiences has been estimated through score, where each sub-question's conceivable score varies from 1 to 5 . According to the table below, the score of chance has been gotten through whole activities from its shaping inquiries (for example chance of accessing higher education are acquired from scores on sub-question number 10 and 11) and so does the score of chance of being financially literate (sub-question number 14, 15 and 40). Referring to score of chances' compositions, each score has different range of values caused by the different number of forming inquiries.

Score of higher education access chance has a possible range value from 1 to 10 (since it has been formed by 2 sub-questions where each of them worth 1 to 5 ). The 1 score stands for a meager chance of accessing higher education, and 10 stands for a very high chance of higher education access. The score of chance in higher education access is expected to boost-positively correlated-to the probability of participation in waste-handling training. Financial literacy scores have a possible range value from 1 to 15 (formed by 3 sub-questions). The chance of financially literate the 1 score stands for very low ability to make financial plans (indicating low financial literacy on women), and 15 stands for very high ability to make financial plans. Score of financial literacy is expected to boost-positively correlateto the probability of participation in waste-handling training. 


\subsubsection{The logistic regression model}

The analysis of this study used a logistic regression model to estimate women's probability of participating in waste-handling training. The dependent variable is the dummy variable of women's pro-environmental behavior with the indicator of participation on waste-handling training, where 1 stands for participated and 0 stands for not participated. Logistic regression estimates the probability of dummy dependent variable from several chosen regressors (independent variables). As described before, the chance of getting higher education and financial literacy become the two variables of interests - are they really matters to urban wastehandling training participation on observed women.

On the logistic regression, continuous regressor will contribute to the probability of dependent variable occurrence, by the amount of its coefficient parameter [12]. This is called marginal effect interpretation, where it's used to analyze how continuous regressor affects the probability of participation in waste-handling training. In marginal effect it may increase or decrease the probability according to the respective positive or negative coefficient parameter. The interpretation through marginal effect is the probability of dependent variable will increase/decrease by the number of coefficient parameter, if the independent variable has increased by 1 (e.g. the probability of attending waste-handling training will decrease $0 . x$ if the score of discrimination increased by 1 ).

The dummy regressor in the other hand, will contribute to the probability by the amount of ratio shown by its coefficient parameters. This is called odds ratio interpretation, where it's used to analyze how dummy regressor affects the dependent variable. Odds ratio coefficient parameters do not have any negative numbers. Yet, in order to express negative impact to the probability of attending training it will show a below-one coefficient parameter $(0<\mathrm{X}<1)$. The above-one coefficient parameter shows positive impact to the dependent variable. The interpretation through odds-ratio is the probability of dependent variable (participation in waste-handling training) will likely $\mathrm{X}$ times higher, if the dummy variable is 1 (where $\mathrm{X}$ is the odds ratio or coefficient parameter of the dummy variable). The model has two dummy independent variables, such are technological adaptations and internet usage. The model also includes categorical dummy of economic status and respondents' activities, which has same interpretation way with the odds-ratio.

Another independent variable regressed in this study are years of schooling (and its squared form), categorical dummy of activities, categorical dummy of economic status, and dummy of internet access and ability to adapt with technology. The categorical dummy of economic status divides samples into 3 categories: (i) low income (below USD 70 per month, (ii) middle income (between USD 71-210 per month), and (iii) high income (above USD 210 per month). The categorical dummy of activities meanwhile divides the sample into several main activities. At a glance, these categories might similar with working status, yet it's different from BPS's definition of work status. The categories of main activities are (i) housewives, (ii) part-time-workers, (iii) retired, (iv) self-employed, (v) student, (vi) unworked, and (vii) worked. Socio-economic independent variables included in the model are the control variable of the dependent variable. The regression model specified as follows: 


$$
p=\frac{1}{1+e^{-\left(\beta_{0}+\beta_{1} X_{1}+\beta_{2} X_{2}+\beta_{3} X_{3}+\ldots+\beta_{9} X_{9}+\varepsilon\right)}}
$$

Where,$$
p
$$

$\begin{array}{ll}e & =\text { exponential number } \\ \beta_{0}-\beta_{9} & =\text { coefficient parameters }\end{array}$

$X_{1}$

$=$ score of chance of access to higher education

$X_{2}$

$=$ score of chance of getting good environment

$X_{3}$

$=$ score of chance to be financially literate

$X_{4}$

$=$ Years of Schooling

$X_{5}$

$=$ Years of Schooling ${ }^{\wedge} 2$

$X_{6}$

= Categorical dummy of activities (base comparator: housewife)

$X_{7} \quad=$ Categorical dummy of economic status (base comparator: high-income)
$X_{8} \quad=$ Dummy variable of access to internet (1=has access)
$X_{9} \quad=$ Dummy variable of ability to adapt with technology (1=able to adapt $)$
$\varepsilon \quad=$ Error terms

\section{Result and discussion}

Based on the results of statistical tests conducted, Table 1 shows the crosstabulation test results based on the respondent's activity and its relation to the respondent's demographics.

Table 1. The cross-tabulations analysis result

\begin{tabular}{|c|c|c|c|c|c|c|c|c|}
\hline & Housewife & $\begin{array}{l}\text { Part-time } \\
\text { workers }\end{array}$ & Retired & $\begin{array}{l}\text { Self- } \\
\text { employed }\end{array}$ & Student & Unworked & Worked & Total \\
\hline \multicolumn{8}{|c|}{ Waste-Handling training } \\
\hline No & 71 & 50 & 4 & 51 & 62 & 13 & 37 & 288 \\
\hline Yes & 28 & 9 & 0 & 14 & 32 & 4 & 20 & 107 \\
\hline Total & 99 & 59 & 4 & 65 & 94 & 17 & 57 & 395 \\
\hline \multicolumn{1}{|c|}{ Business \& Entrepreneurship Training } \\
\hline Yes & 25 & 19 & 0 & 18 & 40 & 5 & 18 & 125 \\
\hline No & 74 & 40 & 4 & 47 & 54 & 12 & 40 & 271 \\
\hline Total & 99 & 59 & 4 & 65 & 94 & 17 & 58 & 396 \\
\hline
\end{tabular}




\begin{tabular}{|c|c|c|c|c|c|c|c|c|}
\hline \multicolumn{9}{|c|}{ Access to Internet } \\
\hline No & 38 & 8 & 0 & 21 & 18 & 4 & 12 & 101 \\
\hline Yes & 61 & 51 & 4 & 45 & 76 & 13 & 46 & 296 \\
\hline Total & 99 & 59 & 4 & 66 & 94 & 17 & 58 & 397 \\
\hline \multicolumn{9}{|c|}{ Adapt to Technology } \\
\hline No & 8 & 8 & 1 & 11 & 7 & 1 & 6 & 42 \\
\hline Yes & 91 & 51 & 3 & 55 & 87 & 16 & 52 & 355 \\
\hline Total & 99 & 59 & 4 & 66 & 94 & 17 & 58 & 397 \\
\hline \multicolumn{9}{|c|}{ Economic Status } \\
\hline $\begin{array}{l}\text { High } \\
\text { Income }\end{array}$ & 66 & 36 & 4 & 39 & 9 & 6 & 30 & 190 \\
\hline $\begin{array}{l}\text { Low } \\
\text { Income }\end{array}$ & 7 & 6 & 0 & 8 & 50 & 4 & 5 & 80 \\
\hline $\begin{array}{l}\text { Middle } \\
\text { Income }\end{array}$ & 26 & 16 & 0 & 19 & 33 & 7 & 23 & 124 \\
\hline Total & 99 & 58 & 4 & 66 & 92 & 17 & 58 & 394 \\
\hline \multicolumn{9}{|c|}{ Age } \\
\hline Adult & 47 & 38 & 0 & 27 & 9 & 4 & 31 & 156 \\
\hline Elderly & 8 & 1 & 1 & 6 & 0 & 0 & 2 & 18 \\
\hline Mature & 35 & 6 & 2 & 24 & 1 & 4 & 8 & 80 \\
\hline $\begin{array}{l}\text { Senior } \\
\text { Citizen }\end{array}$ & 1 & 0 & 1 & 0 & 0 & 0 & 0 & 2 \\
\hline $\begin{array}{l}\text { Young } \\
\text { Adult }\end{array}$ & 8 & 14 & 0 & 9 & 84 & 9 & 17 & 141 \\
\hline Total & 99 & 59 & 4 & 66 & 94 & 17 & 58 & 397 \\
\hline \multicolumn{9}{|c|}{ Marital Status } \\
\hline Divorced & 1 & 1 & 0 & 3 & 0 & 1 & 0 & 6 \\
\hline Married & 94 & 37 & 4 & 48 & 2 & 7 & 30 & 222 \\
\hline Unmarried & 3 & 20 & 0 & 14 & 92 & 9 & 26 & 164 \\
\hline Total & 98 & 58 & 4 & 65 & 94 & 17 & 56 & 392 \\
\hline \multicolumn{9}{|c|}{ Duration of Living } \\
\hline $\begin{array}{c}\text { Early } \\
\text { Resident }\end{array}$ & 7 & 13 & 0 & 10 & 13 & 1 & 9 & 53 \\
\hline Inhabitants & 65 & 13 & 1 & 36 & 42 & 8 & 22 & 187 \\
\hline $\begin{array}{c}\text { New } \\
\text { Resident }\end{array}$ & 2 & 2 & 0 & 2 & 17 & 3 & 9 & 35 \\
\hline Resident & 17 & 24 & 0 & 12 & 11 & 5 & 12 & 81 \\
\hline $\begin{array}{c}\text { Senior } \\
\text { Resident }\end{array}$ & 8 & 7 & 3 & 6 & 7 & 0 & 5 & 36 \\
\hline Total & 99 & 59 & 4 & 66 & 90 & 17 & 57 & 392 \\
\hline \multicolumn{9}{|c|}{ Years of Schooling } \\
\hline Mean & 11.17 & 13.05 & 16.00 & 10.82 & 12.00 & 11.76 & 14.16 & 12.10 \\
\hline Std. Dev. & 2.68 & 2.31 & 0.00 & 3.51 & 1.93 & 2.31 & 2.43 & 2.81 \\
\hline Freq. & 99 & 59 & 4 & 66 & 94 & 17 & 58 & 397 \\
\hline \multicolumn{9}{|c|}{ Chance to earn good living environment } \\
\hline Mean & 14.12 & 14.92 & 15.50 & 14.20 & 14.83 & 14.12 & 14.29 & 14.46 \\
\hline
\end{tabular}




\begin{tabular}{|c|c|c|c|c|c|c|c|c|}
\hline Std. Dev. & 3.09 & 3.84 & 2.89 & 3.09 & 3.01 & 2.34 & 3.64 & 3.25 \\
\hline Freq. & 99 & 59 & 4 & 66 & 94 & 17 & 58 & 397 \\
\hline \multicolumn{8}{|c|}{ Chance of access higher education } \\
\hline Mean & 5.75 & 5.86 & 7.50 & 5.29 & 6.39 & 5.53 & 6.24 & 5.92 \\
\hline Std. Dev. & 1.53 & 1.53 & 1.29 & 1.72 & 1.60 & 1.01 & 1.45 & 1.59 \\
\hline Freq. & 99 & 59 & 4 & 66 & 94 & 17 & 58 & 397 \\
\hline \multicolumn{8}{|c|}{ Chance of financial literacy } \\
\hline Mean & 7.47 & 7.68 & 11.00 & 8.48 & 7.48 & 7.06 & 7.69 & 7.72 \\
\hline Std. Dev. & 1.79 & 1.89 & 0.82 & 2.11 & 2.18 & 1.43 & 1.78 & 1.99 \\
\hline Freq. & 99 & 59 & 4 & 66 & 94 & 17 & 58 & 397 \\
\hline
\end{tabular}

(Source: Research finding (private document), 2020)

Table 1 shows that the number of respondents who attended the most waste handling training was homemakers and female students. This result shows proenvironmental behavior driving with awareness about the effect of environmental degradation. This study is related to the study of women's role in household waste management and the existence of family welfare orientation factors that encourage homemakers to improve their knowledge and skills in waste management [13]. According to the previous chapter's stated regression model, the following table shows how the dependent variable (probability to attend waste-handling training) interacts with other exogenous variables in Table 2.

Table 2. The regression analysis result

\begin{tabular}{|c|c|c|c|c|c|c|}
\hline & $(1)$ & $(2)$ & $(3)$ & $(4)$ & $(5)$ & $(6)$ \\
\hline & est7 & est8 & est9 & est10 & est11 & est12 \\
\hline VARIABLES & \multicolumn{5}{|c|}{ Probability to Attend Waste-Handling Enrichment } \\
\hline $\begin{array}{c}\text { Chance to Earn } \\
\text { Higher Education }\end{array}$ & $0.169^{*}$ & $0.170^{*}$ & 0.124 & 0.128 & $0.162^{*}$ & $0.160^{*}$ \\
\hline & $(0.0897)$ & $(0.0910)$ & $(0.0946)$ & $(0.0959)$ & $(0.0969)$ & $(0.0970)$ \\
\hline $\begin{array}{c}\text { Chance to Earn } \\
\text { Good Living } \\
\text { Environment }\end{array}$ & $0.0731^{*}$ & $0.0731^{*}$ & $0.0878^{*}$ & $0.0940^{* *}$ & $0.0932^{* *}$ & $0.0937^{*}$ \\
\hline & $(0.0432)$ & $(0.0433)$ & $(0.0451)$ & $(0.0455)$ & $(0.0457)$ & $(0.0459)$ \\
\hline $\begin{array}{c}\text { Chance of } \\
\text { Financial Literacy }\end{array}$ & -0.108 & -0.109 & -0.0773 & -0.0956 & -0.0883 & -0.0907 \\
\hline & $(0.0688)$ & $(0.0693)$ & $(0.0728)$ & $(0.0739)$ & $(0.0741)$ & $(0.0744)$ \\
\hline Years of Schooling & -0.0227 & -0.0392 & -0.0816 & -0.0881 & -0.0387 & -0.0291 \\
\hline & $(0.0431)$ & $(0.259)$ & $(0.270)$ & $(0.271)$ & $(0.275)$ & $(0.276)$ \\
\hline $\begin{array}{c}\text { Years of } \\
\text { Schooling^2 }\end{array}$ & & 0.000700 & 0.00280 & 0.00253 & 0.000767 & 0.000417 \\
\hline & $(0.0109)$ & $(0.0114)$ & $(0.0115)$ & $(0.0117)$ & $(0.0117)$ \\
\hline $\begin{array}{c}\text { Activities = Part } \\
\text { time worker }\end{array}$ & & & $0.429^{*}$ & $0.451^{*}$ & 0.520 & 0.528 \\
\hline & & $(0.441)$ & $(0.443)$ & $(0.450)$ & $(0.451)$ \\
\hline
\end{tabular}




\begin{tabular}{|c|c|c|c|c|c|c|}
\hline \multirow{2}{*}{$\begin{array}{c}\text { Activities = Self- } \\
\text { employed }\end{array}$} & & & 0.772 & 0.811 & 0.871 & 0.890 \\
\hline & & & $(0.393)$ & $(0.395)$ & $(0.400)$ & $(0.403)$ \\
\hline \multirow{2}{*}{$\begin{array}{c}\text { Activities }= \\
\text { Student }\end{array}$} & & & 1.164 & 1.448 & 1.752 & 1.742 \\
\hline & & & $(0.324)$ & $(0.382)$ & $(0.397)$ & $(0.397)$ \\
\hline \multirow{2}{*}{$\begin{array}{c}\text { Activities = } \\
\text { Unworked }\end{array}$} & & & 0.798 & 0.900 & 1.054 & 1.043 \\
\hline & & & $(0.619)$ & $(0.627)$ & $(0.634)$ & $(0.635)$ \\
\hline \multirow{2}{*}{$\begin{array}{c}\text { Activities }= \\
\text { Worked }\end{array}$} & & & 1.353 & 1.473 & 1.664 & 1.667 \\
\hline & & & $(0.390)$ & $(0.399)$ & $(0.407)$ & (0.407) \\
\hline \multirow{2}{*}{$\begin{array}{l}\text { Econ. Status = } \\
\text { Low Income }\end{array}$} & & & & 0.572 & $0.516^{*}$ & $0.519 *$ \\
\hline & & & & $(0.385)$ & $(0.395)$ & $(0.395)$ \\
\hline \multirow{2}{*}{$\begin{array}{l}\text { Econ. Status = } \\
\text { Middle Income }\end{array}$} & & & & 0.783 & 0.703 & 0.713 \\
\hline & & & & $(0.289)$ & $(0.296)$ & $(0.297)$ \\
\hline \multirow{2}{*}{$\begin{array}{c}\text { Dummy - Access } \\
\text { to Internet }\end{array}$} & & & & & $0.486 * * *$ & $0.479 * * *$ \\
\hline & & & & & $(0.277)$ & $(0.278)$ \\
\hline \multirow{2}{*}{$\begin{array}{c}\text { Dummy - Ability } \\
\text { to Adapt with } \\
\text { Technology }\end{array}$} & & & & & & 1.234 \\
\hline & & & & & & $(0.422)$ \\
\hline \multirow[t]{2}{*}{ Constant } & $-1.943 * *$ & -1.854 & -1.785 & -1.547 & -1.654 & -1.879 \\
\hline & $(0.758)$ & $(1.582)$ & (1.640) & $(1.650)$ & (1.673) & (1.737) \\
\hline Observations & 397 & 397 & 391 & 388 & 388 & 388 \\
\hline
\end{tabular}

Standard errors in parentheses: *** $\mathrm{p}<0.01, * * \mathrm{p}<0.05,{ }^{*} \mathrm{p}<0.1$

(Source: Research finding (private document), 2020)

This study author has tested many possible models related to the framework of thinking, with tested possible estimations. Six possible estimates explain the impact of chance on getting higher education, financial literacy, and other independent variables from the demographics aspect to the probability of participation in wastehandling training in the past 3 months. According to the regression table above, the chance of accessing higher education positively impacts the likelihood of women's participation on waste-handling training. An increase of score of higher education access by 1 could increase the likelihood by 0.16 (estimation 6 ) and statistically significant at $90 \%$ confidence level. The marginal effect increase shown by higher education access is relatively high compared to other independent variables. This finding matched with the previous studies, where individuals with higher education access are expected to care and contribute more to the environment, ignoring the 
level of self-ignorance. This indicate that if urban women have access to higher educational stages, their likelihood to participate on science-based environmental preservations will increase.

Then, the independent variable of financial literacy on women. It's shown that financial literacy has negative correlation to the likelihood of participation. Through marginal effect participation, it shows that an increase of score of financial literacy by 1 will likely to decrease the likelihood by 0.0907 , without any significant statistical impact. This finding is contrary with the previous studies, where educated and financially literate women are expected to participate more on environmental conservations. Related with access of education, the score of years of schooling and its squared form. On estimation 6, it shows that years of schooling has negative impact to the likelihood, while its squared form has positive impact to the likelihood. Same patterns seen on all estimations. Although it's not statistically significant, this finding still interesting since years of schooling often shows a quadratic relationship to the dependent variable - in this case the likelihood of women's participation on waste-handling training. Years of schooling has negative impact to the dependent variable since there's minimum education stage (minimum years of schooling) that must be taken in order to takes effect on changing human behavior. Since it has minimum years of schooling in order to increase environmental awareness, the squared form of years of schooling is expected to have positive relationship, to form a U-shaped correlation curve relative to the dependent variable.

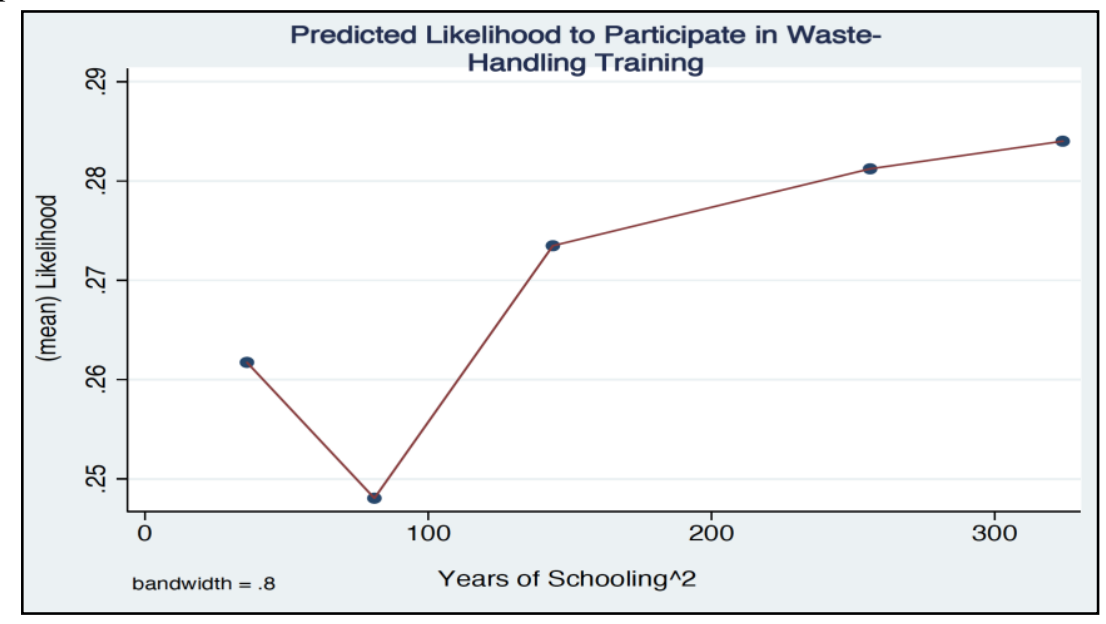

Fig 2. The U-Shaped curve between the predicted likelihood \& Years of Schooling (Source: Research finding (private document), 2020)

Figure 2 shows minimum schooling (approximately nine years/junior high school equivalent) to reshape the respondent's behavior. The next independent variable is the categorical dummy of activities, where the housewife is the base comparator (Housewives' odds ratio estimates $=1$ ). According to the regression table above, part-time and self-employed women tend to have a lower participation rate. Their likelihood of participating in waste-handling training is 0.528 and 0.890 
times lower than homemakers. Retired women have been omitted since it does not have enough variation in the regression process.

In contrast, students who worked and unworked women will likely have more participation rates in waste-handling training. Their probability of participating in waste-handling training will tend to be $1.742,1.667$, and 1.043 times higher, respectively, compared to the housewives. However, all odds ratios shown by the categories of respondents' main activities are not statistically significant.

The next sub-variable from the demographics aspect is the chance to get a suitable living environment. This variable has been included in this article to see the respondent's available house locations' available choices and preferences. Shortly this variable is to detect whether respondents whose house is relatively good in terms of environment will likely participate more in waste-handling training. According to the regression result, it shows a significant and positive impact on the likelihood of participation. An increase of this score by one could increase the likelihood by 0.0937 (estimation 6), and it is statistically significant at a $95 \%$ confidence level. This finding indicates that highly participated women in wastehandling training are agglomerated in clean and well-organized environments.

In the next categorical dummy sub variable is economic status. Recall that the base comparator is high-income respondents. Referring to the regression table, lowincome respondents tend to have less likelihood of participation by 0.519 times lower than high-income ones. It is statistically significant at a $90 \%$ confidence level. This finding indicates that participation in waste-handling training is somewhat tertiary since low-income women participate less in these activities.

Furthermore, this finding also confirms that women from lower-income classes prioritize earning a living rather than participating in waste-handling training. Middle-income women show a similar pattern (having less likelihood of participation by 0.713 times lower), yet the result is statistically insignificant. The last independent variables are the dummy of internet access and the ability to adapt to technology. Women with access to the internet have a significantly lower participation rate than women who do not have internet access. Their likelihood to participate will likely 0.479 times lower (estimation 6) than those who do not have access, and it is statistically significant at a $99 \%$ confidence level. This finding indicates that internet access might shift their physical presence on waste-handling training, assuming they are not lazy to take care of the environment. On the other side, this finding might also indicate that the internet could shift their attention from environmental activities to virtual social activities. The different patterns are shown by the dummy variable of the ability to adapt to the technology. Women with the ability to adapt to technology will likely have more participation rates than unable. Their likelihood will tend to be 1.23 times higher than the unable. However, the result is statistically insignificant.

The findings show that there are several factors related to the background of women. It is hoped that they can participate more in environmental preservation for educated women and have financial literacy, supported by their access, encouragement of a clean and organized living situation, environmental management, availability of time, and the ability to use technology. However, financial education does not have a significant relationship with pro-environmental behavior. The existence of socio-demographic factors of women determines the possibility of access to education. Women from middle-high economic status backgrounds who can access more comprehensive education will increase 
environmental awareness. Pro-environmental behavior is related to the focus on individual welfare because women from low-income backgrounds prioritize earning a living rather than being involved in environmental management activities.

The social and environmental conditions that are the background of women also shape pro-environmental behavior. The finding is that women who are heavily involved in training in permanent waste management in a clean and well-organized environment. Environmental conditions are clean and well managed because women are concerned about the environment and want to improve their proenvironmental activities. The factor of the type of work and women's routine also shows that women who work part-time and are self-employed tend to have lower participation rates than homemakers. Meanwhile, students, working women, and women who do not work tend to have a higher participation rate than homemakers. This condition explains that the availability of time and awareness building to be involved in environmental management is related to the knowledge that women where students and women workers have access to knowledge relatively high in intensity. However, concerning internet access, the internet can divert women's attention from environmental activities to virtual social activities, however, internet access allows women to access environmental issues. Because basically, women with the ability to adapt to technology will tend to have a higher level of participation than women who cannot adapt to technology.

This study's findings also show a correlation between higher education and financial literacy with pro-environmental behavior. However, this study does not explicitly find the boundaries of financial literacy with financial well-being. This is different from the context of financial awareness in the findings of De Silva and Pownall (2014) and Heyman and Ariely (2004) that individuals with higher education tend to provide financial support as a form of environmental quality concern [14]. In this study also shows that women have the motivation to participate in waste management training activities. The training will support the improvement of women's practical skills in implementing waste recycling and sorting. As part of knowledge formation, involvement in training will motivate women in carrying out waste management from household to community level [15]. This shows that women's role in waste management is vital so that women realize the importance of self-development for pro-environmental behavior. Access to education will support the development of women's capacity to develop further. At present, with technological developments and cultural changes, women have rights and must be allowed to continue learning with equal access to education. Women who are housewives, have retired, or are still working (full-time or part-time) can play a role in more sustainable waste management. According to Asi et al. (2013), this finding is by that gender roles are a determining aspect for proactive behavior more sustainable waste handling [16]. Access to higher education is a way of empowering so that women can be more involved in all levels of environmental management and sustainable waste management and have leadership skills [17]. Therefore, the government and decision-makers should consider women's environmental performance to improve women's environmental performance who can support urban solid waste management to achieve urban sustainability.

\section{Conclusion}


This study's conclusion shows a positive and significant relationship between higher education access to pro-environmental behavior involvement by participating in waste management training. Women will be more motivated to be involved in proenvironmental activities when they can develop their abilities in managing the environment. Education is an aspect that shapes women's knowledge so that women can play a role in supporting the sustainability of environmental management in urban areas. Women's opportunities to access education and technology are a way to achieve gender equality in environmental management.

This study's contribution is to develop a study about the formation of environmental knowledge in women with the driving factor that causes education's effectiveness to shape pro-environmental behavior. The length of access to environmental education and orientation to social welfare determines the relationship between education and pro-environmental behavior. Access to environmental education is necessary by integrating formal and informal education in strengthening environmental awareness. Recommendations for further research by conducting evaluation research on the effects of integrating formal and informal education in shaping pro-environmental behavior by testing comparability between women and men to determine its effectiveness.

\section{Acknowledgements}

This research is funded by Program Penelitian Dasar Ungguan Perguruan Tinggi (PDUPT) Kementerian Riset dan Teknologi/Badan Riset dan Inovasi Nasional (KEMENRISTEK/BRIN)-Universitas Indonesia in contract number NKB$130 /$ UN.2.RST/HKP.05.00/2020 with the main contract number 8/E1/KP.PTNBH/2020 and 255/PKS/R/UI/2020.

\section{References}

1. E. Neumayer, T. Plümper, Annals of the Assoc of American Geographers, 97, 551-566 (2017)

2. D. Asteria, H. Herdiansyah, D.J. Haryanto, Women Environmental Literacy in Development of Human Capital for the Management of Household Waste, in Urbanization, Human Capital, and Regional Development: The Indonesia Experiences. Gramedia Pustaka Utama Publishing, 81-107 (2018)

3. Special Eurobarometer 365, Attitudes of European citizens towards the environment. European Commission (2011) http://ec.europa.eu/environment/pdf/ebs 365 en.pdf

4 C. Xiao, R.E. Dunlap, D. Hong, Soc. Sci. Q., 94, 672-690 (2013)

5. J. Tullio, P. Mario, J. of Banking and Finance, 37, 2779-2792 (2013)

6. A. Meyer, Ecological Economics, 116, 108-121 (2015)

7. D.G. De Silva, R.A.J. Pownall, Appl. Econ., 46, 573-586 (2014)

8. L. Mundaca, L. Neij, E. Worrell, M. McNeil, Annu. Rev. Environ. Resour., 35, 305-344 (2010)

9. B. Torgler, M.A. García-Valiñas, Ecol. Econ. 63 (2-3), 536-552 (2007)

10. D. Asteria, H. Herdiansyah, Inter J. of Social Eco and Sustain Dev, 11, 38-50 (2020) 
11. South Jakarta City Statistics Agency,Thematic Map of South Jakarta City 2020, $15(2020)$

12. C.J. Peng, T.H. So, Understanding Statistics, 1, 31-70 (2002)

13. E. Ar1, V. Y1lmaz, Ecological Economics, 129, 132-142 (2016)

14. A. Chakraborty, M.P. Singh, M. Roy, Inter J. of Sustai in Higher Edu, 18, 1291-1310 (2017)

15. A.D. Zand, A.V. Heir, A.M. Tabrizi, Environ Monit Assess, 192, 481 (2020)

16. E. Asi, G. Busch, L. Nkengla, International Conference on Integrated Waste Management and Green Energy Engineering, Johannesburg, South Africa (2013)

17. T. Mino, K. Hanaki (Ed.). Environmental Leadership Capacity Building in Higher Education: Experience and Lessons from Asian Program for Incubation of Environmental Leaders, Springer (2013) 